Institute of $\mathbf{F}_{\text {ood and }} \mathbf{A}_{\text {gricultural }} \mathbf{S}_{\text {ciences }}$

\title{
Cultural Guidelines for Commercial Production of Interiorscape Epipremnum 1
}

\author{
Dennis B. McConnell, Jianjun Chen, Richard J. Henny, and Kelly C. Everitt ${ }^{2}$
}

Epipremnum, a genus in the family Agavaceae, derives its name from a combination of two Greek words: epi meaning "on" and premnon meaning "trunk." This describes the genus and its 10 known species as tree-climbing vines. The only species commercially produced and used as an interiorscape plant is E. aureum, commonly called pothos or devil's ivy. This native of the Solomon Islands is one of the most common interiorscape plants. Millions of these plants have been grown and sold for use indoors during the last 80 years. Surprisingly, it was not until the 1960s that taxonomists finally decided this foliage favorite was a species in the Epipremnum genus. This plant had been previously classified as Pothos aureus, Scindapsus aureus, and Raphidophora aurea. What was the reason for all these name changes? Even in its native habitat pothos seldom flowers, and correct taxonomic classification was only possible when enough flowers were collected in Florida and Puerto Rico for detailed examination. In tropical settings pothos can grow to be large vines, climbing trees 50 feet tall and producing lobed, fenestrate leaves up to three feet in length. Plants used for interiorscapes have heart-shaped leaves that seldom exceed six inches in length. Their growth habit makes all these cultivars useful as totems, hanging baskets, ground covers, pedestal plants, dish gardens, and small desk plants. This article describes common Epipremnum species and cultivars in the foliage plant industry (See Table 1), provides guidelines on their culture and interior use, and lists physiological problems encountered in both production and in the interiorscape (See Table 3).

Table 1. A listing of $E$. aureum cultivars available in Florida as of 2002.

\begin{tabular}{||l|l||}
\hline \hline $\begin{array}{l}\text { Cultivar or Common } \\
\text { Name }\end{array}$ & Characteristics \\
\hline 'Golden Pothos' & $\begin{array}{l}\text { Dark green leaves are freely } \\
\text { but irregularly variegated with } \\
\text { yellow and creamy white } \\
\text { streaks, stripes, and } \\
\text { splashes. }\end{array}$ \\
\hline 'Hawaiian Pothos' & $\begin{array}{l}\text { Variegation patterns are } \\
\text { similar to 'Golden Pothos' but } \\
\text { with a more striking yellow } \\
\text { color. }\end{array}$ \\
\hline 'Jade Pothos' & $\begin{array}{l}\text { Leaves have no variegation. } \\
\text { They are solid green. }\end{array}$ \\
\hline 'Marble Queen' & $\begin{array}{l}\text { Leaves are marbled with } \\
\text { white variegation only. }\end{array}$ \\
\hline \hline
\end{tabular}

1. This document is ENH894, a series of the Environmental Horticulture Department, Institute of Food and Agricultural Sciences, University of Florida. Please visit the EDIS web site at http://edis.ifas.ufl.edu. Original publication date: April 2003.

2. Jianjun Chen, Assistant Professor, Mid-Florida Research and Education Center and Environmental Horticultural Department, Dennis B. McConnell, Professor, Environmental Horticultural Department, Richard J. Henny, Professor, Mid-Florida Research and Education Center and Environmental Horticultural Department, and Kelly C. Everitt, Research Assistant, Mid-Florida Research and Education Center at the Institute of Food and Agricultural Sciences, University of Florida.

The Institute of Food and Agricultural Sciences is an equal opportunity/affirmative action employer authorized to provide research, educational information and other services only to individuals and institutions that function without regard to race, color, sex, age, handicap, or national origin. For information on obtaining other extension publications, contact your county Cooperative Extension Service office. Florida Cooperative Extension Service/Institute of Food and Agricultural Sciences/University of Florida/Christine Taylor Waddill, Dean. 


\section{Cultural Guidelines}

\section{Propagation}

The most common method used to propagate pothos is to make one to $11 / 2$-inch stem cuttings with a node and an attached leaf. Buds break in 2-3 weeks and rooting occurs in 3-4 weeks. If larger leafed cuttings are desired for totems, stock plants are grown on a pole or similar support and tip cuttings are used.

\section{Production}

Sphagnum peat, pine bark, vermiculite, or perlite can be volumetrically combined to formulate media for most container sizes. Three-foot and taller totems should have $10-20 \%$ coarse sand to keep plants from wind tipping. Media should have good moisture-holding capacity and aeration, soluble salts of $3-5 \mathrm{dS} / \mathrm{m}$, and $\mathrm{pH}$ of 6.5 to 7.0 .

Pothos should be grown in a shadehouse with temperature between 70 to $90^{\circ} \mathrm{F}$ and a relative humidity of 60 to $100 \%$. Plant quality and growth rates begin to decline when day temperatures routinely exceed $95^{\circ} \mathrm{F}$ or night temperatures drop below $65^{\circ} \mathrm{F}$. Controlled-release or water-soluble fertilizers, or a combination of both, can be used for pothos production. Use a fertilizer with an $\mathrm{N}: \mathrm{P}: \mathrm{K}$ ratio of $3: 1: 2$ or $3: 1: 3$. The suggested application rate is $5 \mathrm{lb} \mathrm{N}$ per $1,000 \mathrm{sq}$. $\mathrm{ft}$ per month. Table 2 provides a guide for determining if pothos are appropriately fertilized based on leaf analysis.

Pothos should be grown with levels of 63 to $80 \%$ shade ( 3250 to $2500 \mathrm{ft}-\mathrm{c}$ ). Growth rate and color in the variegated cultivars decrease when shade levels are greater than $80 \%$ (2500 ft-c).

\section{Shipping and Interior care}

Pothos should be shipped at temperatures between 55 and $65^{\circ} \mathrm{F}$. Once plants are placed indoors, it is advisable not to re-pot or fertilize for about four weeks because plants do not need additional stresses. Plants should not be fertilized if soluble salts are 3.0 $\mathrm{dS} / \mathrm{m}$ or more. If soluble salt levels are higher than $5.0 \mathrm{dS} / \mathrm{m}$, percolation of media with water may help reduce potential leaf necrosis or damage to the root system. Media should be kept moist. In most interior locations pothos does better if grown "a little on the dry side." They will tolerate light levels as low as $50 \mathrm{fc}$ but new leaves will be small and variegated cultivars will lose color. Light levels of $150 \mathrm{fc}$ or more will maintain color and leaf size. Temperatures of 70 to $80^{\circ} \mathrm{F}$ are recommended. 
Table 2. Nutrient concentrations in Epipremnum leaves.

\begin{tabular}{||l|l|l|l||}
\hline \hline Nutrient & Low & Medium & High \\
\hline Nitrogen (\%) & $<2.6$ & $2.7-3.5$ & $>3.5$ \\
\hline Phosphorus (\%) & $<0.19$ & $0.19-0.5$ & $>0.5$ \\
\hline Potassium (\%) & $<2.9$ & $3.0-4.5$ & $>4.5$ \\
\hline Calcium (\%) & $<0.9$ & $1.0-1.5$ & $>1.5$ \\
\hline Magnesium (\%) & $<0.29$ & $0.30-0.60$ & $>0.6$ \\
\hline Sulfur (\%) & $<0.19$ & $0.2-0.5$ & $>0.5$ \\
\hline Iron (ppm) & $<49$ & $50-300$ & $>300$ \\
\hline Manganese (ppm) & $<35$ & $50-300$ & $>300$ \\
\hline Zinc (ppm) & $<19$ & $20-200$ & $>200$ \\
\hline Copper (ppm) & $<5$ & $6-50$ & $>50$ \\
\hline Boron (ppm) & $<19$ & $20-50$ & $>50$ \\
\hline \hline
\end{tabular}

Table 3. Causes and effects of various physiological problems.

\begin{tabular}{||l|l|l||}
\hline \hline Symptoms & Cause & Treatment \\
\hline $\begin{array}{l}\text { Scattered brown patches in center of } \\
\text { the leaf. }\end{array}$ & $\begin{array}{l}\text { Exposure to } 33-40^{\circ} \mathrm{F} \text { for several } \\
\text { hours or abrupt temperature } \\
\text { changes. }\end{array}$ & $\begin{array}{l}\text { Avoid low temperatures and abrupt } \\
\text { temperature changes. }\end{array}$ \\
\hline Older leaves turn yellow. & $\begin{array}{l}\text { Potting media is either kept too dry } \\
\text { or too wet. }\end{array}$ & $\begin{array}{l}\text { Check moisture level of potting and } \\
\text { change irrigation practices } \\
\text { accordingly. }\end{array}$ \\
\hline $\begin{array}{l}\text { New leaves lack variegation and are } \\
\text { smaller than older leaves upon } \\
\text { maturation. }\end{array}$ & $\begin{array}{l}\text { Production light levels are too low, } \\
\text { plants may be magnesium deficient, } \\
\text { or fertilizer rates are too low. }\end{array}$ & $\begin{array}{l}\text { Increase production light levels. } \\
\text { Apply magnesium nitrate spays. } \\
\text { Use recommended fertilizer rates. }\end{array}$ \\
\hline $\begin{array}{l}\text { Burned, necrotic patches confined to } \\
\text { the variegated areas. }\end{array}$ & High light or heat. & $\begin{array}{l}\text { Remove plant from excessive heat } \\
\text { or light into a more appropriate } \\
\text { area. Leaves cannot recover. }\end{array}$ \\
\hline \hline
\end{tabular}

